\title{
THE CONCEPTION OF POPULARITY IN THE ENLIGHTENMENT AND ROMANTICISM
}

It can hardly be disputed that the theme of popularity is central to the Enlightenment. Popularity is the sociality equivalent to the individual appeal: 'Dare to know.' Parallel to this runs the following imperative: 'Dare to encourage your neighbour and your fellow man and woman to think on their own - even though they do not belong to the erudite elite.' It is also undeniable that Romantic authors and philosophers polemically attempted to tear down the popularity project of the Enlightenment, their main criticism being its tendency towards mediocrity. It is less well known that Romantic authors and philosophers themselves, around the turn of the nineteenth century, made popularity their central concern. To quote Friedrich Schlegel in the journal Athenaeum: 'The time of popularity has come.' This article explores the Romantics' alternative conception of popularity, with especial reference to Johann Gottlieb Fichte and the Grimm brothers. To this end, it is helpful to reconstruct the background of the Romantic attempt to create an independent concept of popularity: the debate between Immanuel Kant and the German popular philosopher Christian Garve on the necessity, possibilities, and limits of popularity.

KEY WO R D S Kant, Garve, Fichte, F. Schlegel, Grimm.

By choosing to view the constellation of the Enlightenment and Romanticism exclusively as a binary opposition, the range of each term is narrowed down considerably, while the complex relationship between continuity and discontinuity is reduced. Conversely, by underexposing the difference between the Enlightenment and Romanticism, one important finding can be easily overlooked: the insight into the selectivity of a paradigm shift around 1800 .

However, the following consideration may help to elude this predicament between either narrowing down the focus by overstressing the differences between the Enlightenment and Romanticism or diluting them by underexposure: In conjunction with the call for independent thought and autonomy, Romanticism can be seen as the sometimes problematic attempt at a second, more radical Enlightenment. From such a perspective, Romanticism addresses the immanent contradictions, exclusions and dogmas of the first Enlightenment and tries to 
deconstruct them or at least to expand and complete them, thereby naturally creating its own new dogmas, contradictions, and exclusions.

Such a view of the constellation of the Enlightenment and Romanticism distances itself from the traditional hermeneutic-harmonic model of a 'dialogue of the ages' which merely deals with questions and responses. Instead, it pays at least equal attention to the destructive, polemic energies of knowledge. Not only did Romantic authors and philosophers address the questions which had been left unanswered by the Enlightenment and suggest their own solutions, they also positively zeroed in on the aporias, exclusions, and taboos of the Enlightenment. They were determined to go beyond the boundaries of that era in order to continue the Enlightenment in a highly idiosyncratic manner. Such a perspective on two different forms of Enlightenment with their respective achievements and aporias enables the modern reader to create historical distance and precision. The problem of popularity provides a case in point of the Romantic tendency to continue, through deconstruction, the Enlightenment.

It can hardly be disputed that popularity is one of the central themes of the Enlightenment. Popularity is the 'sociality' equivalent to the individual appeal: 'Habe Mut, dich deines eigenen Verstandes zu bedienen' [dare to know] - and it goes as follows: Dare to encourage your neighbour, colleague and your fellow man and woman to think on their own. ${ }^{1}$ Through this collective appeal, the tenet of the Enlightenment - that man has a universal capacity for rational thought - is put to practical use. It is the call for everyone to engage in universal and public reasoning about the affairs of human society. Everyone, even if they lack expert knowledge or have not undertaken prolonged studies; everyone regardless of social status or class, as long as they are eager to learn, unafraid to think, given to observation and open to new experiences and to sharing them with others. ${ }^{2}$ The Enlightenment's conception of popularity is a universal concept with utopian tendencies.

It is equally undisputed that the Romantic authors and philosophers tried polemically to deconstruct this conception of popularity preferably with regard to its specification in popular philosophy. It is those authors and philosophers this article will focus on. They mainly reproach the Enlightenment's conception of popularity with having a tendency to foster mediocrity. To quote Friedrich Schlegel: 'Der Abriman des Zeitalters ist die Mediokrität; Garve und Nicolai dürften es bis zur Religion dabin gebracht haben. Voß und Wieland für Poesie. Matthison in der Nullität' [The Ahriman of that age is mediocrity; Garve and Nicolai have arguably made it their religion. Voß and Wieland did the same for poetry. Matthison in nullity]. ${ }^{3}$

Among other things, the shrill polemics against the conception of popularity within popular philosophy has led to both non-academics and academics labelling Romanticism as elitist, avant-garde, exotic and sinister rather than as popular. This view is exemplified by the last statement of an article on popular philosophy in the Lexikon der Aufklärung [Encyclopaedia of the Enlightenment]. It says: Popular philosophy 'wurde sehr bald von J. G. Fichte, der einen "neuen vornehmen Ton" in die Philosophie einfübrte und seinen Schülern überholt' [was soon made 
obsolete by J. G. Fichte and his disciples who introduced a 'new refined tone' into philosophy]. ${ }^{4}$ According to this summary, philosophy 'wurde wieder einmal elitär und antipopulär' [once again became elitist and anti-popular]. ${ }^{5}$ In contrast to this prejudice, Friedrich Schlegel formulates the following programmatic thought in the magazine Athenaeum published by himself and his brother in 1799: 'die Zeit der Popularität ist gekommen' [the time of popularity has come]. ${ }^{6}$ Correspondingly, he states in the 1803 edition of his magazine Europa that the philosopher Fichte was 'gegenwärtig am meisten' [currently most] interested 'für die literarische Form' [in literary form] and hence in popularity. ${ }^{7}$ In Athenaeum, F. Schlegel had already presented Fichte as an important role model for popular philosophical writing. Having declared his intention 'die Schriften des berübmten Kant, der so oft über die Unvollkommenheit seiner Darstellung klagt, durch Umschrift verständlich zu machen' [to rewrite the texts of the famous Kant, who himself often deplores the imperfection of his descriptions, in order to make them more intelligible], ${ }^{8}$ he goes on to write in his essay 'Über Philosophie' [On Philosophy]:

Bei Fichte wäre ein solches Verfahren sehr überflüssig. Noch nie sind die Resultate der tiefsten und wie ins Unendliche fortgesetzten Reflexion mit der Popularität und Klarbeit ausgedrückt [worden]. ... Es ist mir interessant, dass ein Denker, dessen einziges großes Ziel die Wissenschaftlichkeit der Philosophie ist, und der das künstliche Denken vielleicht mebr in seiner Gewalt hat, als irgendeiner seiner Vorgänger, doch auch für die allgemeinste Mitteilung so begeistert sein kann. Ich halte diese Popularität für eine Annäherung der Philosophie zur Humanität im wabren und großen Sinne des Worts, wo es erinnert, dass der Mensch nur unter Menschen leben, und so weit sein Geist auch um sich greift, am Ende doch dabin wieder heimkehren soll. Er hat auch bierin seinen Willen mit eiserner Kraft durchgesetzt, und seine neuesten Schriften sind freundschaftliche Gespräche mit dem Leser, in dem treuherzigen, schlichten Style eines Luther'

[Such a procedure would be highly unnecessary with regard to Fichte's work. Never before have the results of the most profound and virtually infinite reflection been expressed with such popularity and clarity... I find it intriguing that a thinker whose sole major purpose is the scientific nature of philosophy and whose mastery of abstract thinking probably surpasses that of all of his predecessors can nevertheless find enthusiasm for the most common of messages. I consider this popularity to be philosophy's approach to humanity in the truest sense of the word - reminding us that man can only live among men and that eventually, he will always return home to their company, regardless of how far his mind may reach. He [Fichte] has been adamant to make his point in this regard as well, and his latest texts are friendly conversations with the reader in the trusting, plain style of Luther.] $]^{9}$

It seems obvious: During Romanticism, popularity is at least as emotionally charged and imperative as it was during the Enlightenment. ${ }^{10}$ Friedrich Schlegel writes: '[I]st es die Bestimmung des Autors, die Poesie und die Philosophie unter die Menschen zu verbreiten und für's Leben und aus dem Leben zu bilden: so ist Popularität seine erste Pflicht und sein böchstes Ziel' [If it is the author's vocation to create poetry and philosophy from life and with life in mind and to spread them among his fellow men: then popularity is his first duty and his highest aim]. ${ }^{11}$ 
However, Romanticism only deserves to be called an attempt at a second Enlightenment if it manages the Herculean task of popularising an esoteric, avantgardiste, non-empirical way of thinking and writing as a more radical, autonomous way of thinking.

Thus, the structure of this article can be outlined as follows:

1. Sketching out the universal concept of popularity as conceived by popular philosophy - predominantly with regard to the explosiveness of the controversial discussion between Garve and Kant about the limits of popularity within philosophy.

2. Reconstructing the relentless, polemical way in which this concept of popularity was analysed by the Romantic authors and philosophers - and to extrapolate their Romantic alternative.

\section{The Universal Concept of Popular Philosophy and its Limits}

Even in its specific form within popular philosophy, the concept of popularity during the Enlightenment is a universal one. This means that it has become effective and left its mark 'in jedem auch noch so untergeordneten Kreise des Lebens' [in every sphere of life, no matter how subordinate $],{ }^{12}$ in communication, in the circulation of knowledge, in the habitus, in the style of thinking, writing, and living. The first and accentuating achievement of popular philosophy was to liberate the arts and philosophy from the ghetto of a business run by specialists and experts as it had been established by scholarly philosophy. Consequently, this led to the focus being shifted from logic epistemology and metaphysics to moral philosophy, psychology, anthropology, and new aesthetics, i.e. to empirical sciences and worldly philosophy. Secondly, popular philosophy makes experiences accessible by creating methods for observation. Its lasting socio-political merit is to have cultivated the art of assuming multiple viewpoints and multiple perspectives in conversations, essays, and historiographical writing. Its specific achievement is the invention of the high art of reasoning, i.e. of turning and weighing different arguments this way and that, and of having them scrutinised by many parties. A new habitus, new media (inter alia journals), new ways and formats of presentation and new mediators as well as a tone of writing and speaking (the so-called conversational tone) which until then had only been reserved for the elite - they all came to serve as a role model and tended to become part of common knowledge. When a new scholarly discipline, aesthetics, emerged around the middle of the 18th century, scholars started to be criticised as pedantic. ${ }^{13}$ They were no longer supposed to educate themselves as specialists, but rather to practise ways of elegant and open communication. Parallel to economic theories, urban ways of life were created in order to link and practise the circulation of knowledge and the know-how of certain ways of speaking and writing. Ramdohr demands: ' $[D]$ ie Gelehrten, die schönen Geister und die Künstler müssen Vereinigung-Punkte haben, wo sie ... besonders mit Welt-und Hofleuten zusammenkommen, und dabei laut sprechen und 
glänzen können. Von dort aus geht dann der Stoff an Hof und Stadt, wird durchgeknetet und zur Speise für jedermann zubereitet' [Scholars, poets and artists need to have a common ground where they . . can convene first and foremost with cosmopolitans and courtiers, and where they can speak freely and scintillate with their wit. From there, the subject matters of their discussions reach the court and the city, where they are kneaded and turned into a palatable meal for everybody]. ${ }^{14}$ Such social gathering points existed in a plethora of variations. They ranged from municipal reading societies to the reading circles of rural nobility and exchanged their ideas via popular science journals (mostly emerging in the wake of English morality weeklies) which had a similar aim of changing general habits. 'Fictitious' authorship provided creative freedom including 'letters', 'dreams' and 'anecdotes' and thus presented the programme of a happy union of entertainment and education. ${ }^{15}$ Gottfried August Bürger claims that 'alle Poesie soll volksmäßig $\operatorname{sein}^{16}$ [all kinds of poetic work ought to be popular], that is 'den mebrsten aus allen Klassen anschaulich und behaglich' [intelligible and pleasing to the majority of every class]. ${ }^{17}$ This is achieved when 'sogleich alles unverschleiert, blank und bar, obne Verwirrung, in das Auge der Phantasie springe' [everything immediately catches the reader's imagination in an unvarnished, bare, simple and unconfused fashion]. ${ }^{18}$ 'Popular philosophy' during the age of Enlightenment deepens and broadens these ambitions by reflecting on the feasibility of a 'Lebhaftigkeit der Darstellung' [vividness of depiction], i.e. a pointed way of writing under a salient perspective or a 'Unterscheidung zwischen Dialog und Erzählung' [distinction between dialogue and narration]. ${ }^{19}$ In his Logik, Immanuel Kant states that '[e]in populärer Vortrag verlangt über die logisch-begriffliche Deutlichkeit hinaus lebendige Bilder, Beispiele in concreto und also ästhetische Deutlichkeit [on top of logical and terminological clarity, a popular disquisition needs vivid images, concrete examples and hence aesthetic clarity]. ${ }^{20}$ The thesis 'Popularität solle nicht sowobl die Gegenstände bezeichnen, welche man behandelt, als die Art und Weise wie man sie behandelt' [popularity ought not to refer to the objects treated, but rather to the way in which they are treated] aims at the standard of an educated, common language. ${ }^{21}$ In this context, it is hard to overstate the importance of the fact that the German popular philosophers often looked across the borders towards England and France.

During the Enlightenment, popular philosophy gained greater currency thanks to the discussion between Christian Garve and Immanuel Kant about the limits of popularity within philosophy. This discussion turns the Enlightenment into an experimental playground. In July and August 1783, it reaches a high-watermark in two letters exchanged between the rivals. Ten years later - in 1793 - it obtains its final form in Garve's balanced reasoning in his essay Von der Popularität des Vortrags [On the popularity of the disquisition]. Garve and Kant's two letters demonstrate what has already been stated earlier in this article (on an intermediate level of abstraction) about the achievement of popular philosophy: First of all, it is noteworthy that the two scholars and authors held each other in high regard (the letter exchange was occasioned by a slating public review of Kritik der reinen Vernunft [Critique of Pure Reason] and Kant's call for the 
anonymous critic to reveal himself to the public). This makes the importance of transparency and clarity within their argumentation understandable. However, one particularly admirable aspect of those letters is the authors' circumspect approach and their willingness to qualify their own judgements. 'Aber das ist auch jetzt noch meine Meynung vielleicht eine irrige' [However, this is my opinion and it may be mistaken], Garve writes before going on to formulate his imperative of the universality of popularity.22 What makes those two letters genuine gems is the formidable sincerity with which the two scholars make references to the state they are in at the time of writing, up to and including the situation in which they are writing (e.g. while on a journey). Garve confesses his reluctance with regard to the cumbersome and unintelligible nature of Kant's text:

Ich will das nicht ganz von mir ablengnen ... dass [ich] über den Schwierigkeiten ... unwillig geworden sei. Ich gestehe, ich bin es zuweilen geworden; weil ich glaubte, es müsse möglich sein, Wabrheiten, die wichtige Reformen in der Philosophie hervorbringen sollen, denen welche des Nachdenkens nicht ganz ungewohnt sind, leichter verständlich zu machen

[I cannot completely deny ... that the difficulties made [me] reluctant. I have to admit that sometimes this was the case; because I believed that it had to be possible for truths aimed at reforming philosophy to be made more intelligible for those not entirely unaccustomed to reflection.] $]^{23}$

And Kant? He is the paragon of commitment: In his turn, he responds to those 'in ihrem geehrten Schreiben deutliche Beweise einer pünktlichen und gewissenhaften Redlichkeit und einer menschlichen teilnehmenden Denkungsart' [clear proofs of a punctual and conscientious integrity and a human, compassionate way of thinking in your revered letter $]^{24}$ with a confession providing insight into his life story as a scholar.

Auch gestehe ich frei, dass ich auf eine geschwinde günstige Aufnabme meiner Schrift gleich zu Anfangs nicht gerechnet habe; denn zu diesem Zwecke war der Vortrag der Materien, die ich mebr als zwölf Jahre bintereinander sorgfältig durchgedacht hatte, nicht der allgemeinen Fasslichkeit gezwungen angemessen ausgearbeitet worden, als wozu noch einige Jahre erforderlich gewesen wären, da ich bingegen in etwa vier bis fünf Monate zu Stande brachte, aus Furcht, ein so weitläufiges Geschäft würde mir, bei längerer Zögerung, endlich selber zur Last werden und meine zunebmenden Jahre (da ich jetzt schon im sechzigsten bin) möchten es mir, der ich jetzt noch das ganze System im Kopf habe, zuletzt vielleicht unmöglich machen

[I must also freely confess that I had not expected my text to be quickly and well received initially; since the disquisition of the subject matters which I had given careful thought to for more than twelve years had not been composed so that it could be commonly understood - a task which would have required several additional years; instead I completed it in just four to five months, fearing that such a comprehensive endeavour would eventually become a burden if I hesitated too long, and that my increasing age (seeing as I am already 60 years old) may eventually prevent me from writing down the entire system which as of now is still fresh in my mind].25 
Embedded in this mutual tone of considerate conversation, there is nevertheless Garve's unequivocal and plain call 'dass das Ganze Ibres Systems, wenn es wirklich brauchbar werden soll, populärer ausgedrückt werden müsse, und es Wabrheit enthält, auch ausgedrückt werden könne; und dass die neue Sprache, welche durchaus in demselben herrscht, so großen Scharfsinn auch der Zusammenhang verrät, in welchen die Ausdrücke derselben gebracht worden, doch oft die in der Wissenschaft selbst vorgenommenen Reform oder die Abweichung von den Gedanken anderer, noch größer erscheinen machen als sie wirklich sind' [for the entirety of your system to be expressed in a more popular manner, should it really be put to use - which ought to be possible as long as it contains truth; and that the new language of this system, however perspicacious the context in which its terms are used, often makes the scholarly reform or the idiosyncrasy of the expressed ideas appear larger than they actually are]. ${ }^{26}$

In his multi-tiered reply, Kant first acknowledges the legitimacy of a call for popularity although he deems it to be absolutely unobtainable when it comes to unfolding the principles of epistemology. ${ }^{27}$ Secondly, Kant asks for the creators of an entirely new system (which cannot avoid introducing new terminology) to be given licence to initially present the system 'als Ganzes' [as a whole] 'in einer gewissen Robigkeit' [in a somewhat rough state] 'eine Zeitlang' [for a certain time]. He hopes that the author himself may afterwards 'explain' and popularise his work piece by piece, in detail and with the help of others (through a 'vereinte Bemühung' [common effort]) so that the 'erste Betäubung' [initial stunning effect] '[die] eine Menge ganz ungewohnter Begriffe und einer noch ungewöbnlicheren Sprache, hervorbringen musste ... verlieren wird' [engendered by a plethora of quite unfamiliar terms and an even more unfamiliar language ... will subside] (an argument Friedrich Schlegel would return to in his essay 'Über Unverständlichkeit' [On unintelligibility]). ${ }^{28}$

Despite his confidence that popularity will gain ground in difficult areas of philosophy, Kant, having weighed all options, still remains sceptical with regard to the attention level of the 'geschmackvolleren Publikums' [more tasteful audience]. ${ }^{29}$

According to him, the 'herrschende Geschmack dieses Zeitalters' [prevailing taste of the age] does not really support such an endeavour: '[D]as Schwere in speculativen Dingen als leicht vorzustellen (nicht leicht zu machen)' [to present the difficult nature of speculative matters in a simple way (not to simplify them)]. ${ }^{30}$

In hindsight, it can be said that in his reasoning and considerations regarding both the necessity and the virtually insurmountable difficulty of achieving a truly 'popular' philosophy, Kant does offer many new points of departure. The authors and philosophers of Romanticism endorse Kant's Zeitgeist diagnosis that an increasing general power of judgement in the area of empirical knowledge has resulted in the already low number of people interested in speculative thought becoming even lower. In his essay on Forster, Friedrich Schlegel returns to Kant's sceptical statement that 'eigentliche Philosophie' [philosophy proper] 'nicht für jedermann sei' [is not for everybody]. ${ }^{31}$ And yet, in the middle of the contemporary 'Sandwüste' [sand desert] of speculative thought, the Romantic philosophers set 
themselves the Herculean task of presenting the difficult nature of speculative matters in a simple manner (as opposed to simplifying them). ${ }^{32}$ For his part, the popular philosopher Garve revisits the difference between the genesis and the ensuing validity of a new system of thought, an aspect of creative theory Kant had addressed in his response letter. In his essay Von der Popularität des Vortrags [On the popularity of the disquisition] (1793), Garve reflects on exceptions from popularity and the ensuing efforts of reintegration necessary for his universal call for popularity to be eventually met. His argumentation is as follows: An inventor cannot be popular since he is forced to assume his own, highly individual point of view that goes against the grain of established knowledge. Rather, he needs to position himself outside the box of 'common sense' in order to arrive at ' $u n$ gewöhnliche Folgerungen und Ideenverknüpfungen'33 [extraordinary conclusions and connections of thought]. Only if this invention has been 'getrennt' [separated] 'von der bloß subjectiven Form des ersten Erfinders' [from the merely subjective form it had been given by the original inventor], 'gesäubert' [cleaned] and 'abgeschliffen' [polished], i.e. once it has been de-individualised and made 'objektiv' [objective] afterwards in a common effort, this invention can be presented in a popular way 'zu größerer Brauchbarkeit' [with more practicality] and more 'Geschmeidigkeit' [elegance]. ${ }^{34}$

\section{Criticism of the Conception of Popularity During the Late Enlightenment and the Presentation of a Romantic Alternative}

This separation of genesis and validity, of the 'dark workshop of thinking' and the polished result, of professional work and presentation, provokes the Romantics' critical and polemic energy. To the Romantic authors, such a dissociation of innovation and popularisation ('Wenn der Geist der Innovation aufhört, kann die Popularisierung beginnen' [popularisation begins where the spirit of innovation ends]) bears witness to how the high good of popularity is degraded to a mere instrument, a vehicle and a rhetorical veil..$^{35}$ For them, 'das allmäbliche Verfertigen des Gedankens' [the gradual development of thought] - i.e. genetic speaking and writing becomes one of the possible roads to popularity. In terms of creative theory, Garve concedes that innovation can only be obtained if we 'unserer Eigenheit mebr nachgebe [n] und daher sich um das Publikum wenig kümmer [n]. Die Denkkraft wird geschwächt, wenn ibr Zwang angetan wird: und unsere Bemühungen unsere Gedanken deutlich zu machen, ist eine Art Zwang' [give more room to our individuality and in turn care little about the audience. Coercion only weakens the power of thought: and our efforts to clarify our thoughts are a kind of coercion]. It is this concession that the Romantic authors pounce upon in a bid to solve the predicament of innovation and popularity. In his essay on Lessing, Friedrich Schlegel suggests that all 'Interesse der öffentlichen Mitteilung' [interest in informing the public] should be abandoned (since it in any case merely fuels the vanity of authors) in exclusive favour of the study of the matter itself, irrespective of public interest. ${ }^{36}$ In doing 
so, i.e. by capturing the matter in a most individual manner, the author may in turn captivate his potential recipient. Certain styles of writing lend themselves particularly well to such reciprocal inspiration- for example the essay: 'Der Essay ist ein wechselseitiger Galvanismus des Autors und des Lesers und auch ein innerer für jeden allein; systematischer Wechsel zwischen Lähmung und Zuckung. - Er soll Motion machen, gegen die geistige Gicht ankämpfen, die Agilität befördern' [The essay is a reciprocal galvanism between the author and the reader, as well as an inner galvanism for every person on their own; a systematic change between paralysis and twitching. - It is meant to cause motion, to battle ossification of the mind, to encourage agility]. ${ }^{37}$ As a consequence, Friedrich Schlegel diagnoses a 'Tendenz unseres Zeitalters, alle Wissenschaften zu essayiren' [tendency of our age to cast all scholarly thought into essays]. ${ }^{38}$

In his essay on Forster, Friedrich Schlegel revisits Kant's sceptical observation that the popularisation of speculative systems of thought was difficult at the time, and proceeds to apply it to the fine arts. Simultaneously, Schlegel gives a positive and productive spin to the power of popularity in terms of fine arts and speculative philosophy, which he regards as the result of division of labour. From this position, he presents Georg Forster as an example of what a decidedly 'social' popular author may look like. Schlegel contends that, unlike the micrology of popular philosophy (which Schleiermacher characterises or rather mocks as 'Anmerkungsphilosophie' [annotative philosophy] $)^{39}$ Forster's work is marked by the far-sighted and globally-oriented author's ability to find concrete terms for experience and vision, entity and detail, urbanity, and virtue. Thus, Friedrich Schlegel has valid and forward-looking legal reasons ${ }^{40}$ to note: 'Die Popularität [ist] ganz eigentlich Prinzip der Autorschaft' [In essence, popularity is the principle of authorship]. ${ }^{41}$

Academics have asserted the importance of Fichte's disquisitions on the Bestimmung des Gelehrten [Vocation of the scholar] for Schlegel's concept of a 'gesellschaftlichen Schriftstellers' [social author] ${ }^{42}$ It is hard to overstate the importance of Fichte's contribution to the conceptualisation of Romantic popularity. For Fichte has removed the pitfalls of the asymmetrical communication structure usually inherent in popularity, with its linear top-down transfer from the expert to the layman. ${ }^{43} \mathrm{He}$ did so by liberating the listeners and readers from their subordinate position and 'constructing' them as future, forward-looking recipients on an equal footing with the author.

Fichte's disquisition 'Über die Bestimmung des Gelehrten’ caught the imagination of his contemporary readers and listeners. It was ground-breaking and formative since it transmuted what had hitherto been conceived of as static knowledge into dynamic knowledge transformation capable of producing new, future-oriented ideas. ${ }^{44}$ The scholar is presented as a leading role-model in society. His analytical diagnosis of the present enables him to design action-changing options with a view to the future, instead of merely accumulating knowledge or at best re-organising it and putting it into perspective (Fichte speaks of 'Eingreifen gewaltig ins Rad der Zeit' [changing the course of history]). ${ }^{45}$ According to Fichte, 
scholars ought to create and 'construct' new and forward-looking thoughts 'genetically' from the inner 'Wurzel seines Lebens' ${ }^{\text {'6 }}$ [root of their lives]. Since these ideas are entirely new and futuristic, they cannot possibly be accounted for by experience and observed accordingly; ${ }^{47}$ it takes an equally new, visionary listener and reader which the author Fichte constructs 'a priori' - and a style which (regardless of all effort) essentially cannot be created willingly and intentionally. Fichte provides an elaborate description of how realisation 'in den von ibr ergriffenen und als Eigentum besessenen Menschen .. . hervorbricht [wells up in the individuals it captures and possesses]. ${ }^{48}$ This is the source of the Romantic concept of popularity, the 'point' at which, in Fichte's words, 'der Gelebrte übergebt in den freien Künstler' [the scholar becomes a liberal artist], '[der] Punkt der Vollendung des Gelehrten'49 [the point of the scholar's completion]. He continues:

Wenn der Philosoph eine Idee in allen ihren einzelnen Bestandteilen Schritt für Schritt zerlegt ... so geht er den Weg der methodischen Mitteilung. ... Gelingt es ibm nun etwa noch zum Beschlusse das Ganze in seiner absoluten Einheit in einen einzigen Lichtstrabl zu fassen, der es wie ein Blitz durchleuchte und abgesondert binstelle, und jeden verständigen Hörer oder Leser ergreife, dass er ausrufen müsse: ja, wabrhaftig, so ist es, jetzt sehe ich es mit einem Male ein: so ist dies die Darstellung der aufgegebenen Idee in ihrer unmittelbaren Anschaulichkeit, oder die Darstellung desselben durch den Witz: und hier zwar durch den direkten, oder positiven Witz [By dissecting an idea step by step, the philosopher follows the path of methodical information. ... If then, upon concluding his work, he succeeds in capturing that idea in its absolute entity as in a single ray of light, illuminating it like lightning, setting it apart and moving every intelligent listener and reader to cry out: yes indeed, this is it, now it all makes sense: then, this idea has been presented in its immediate clarity, or through wit: that is, through direct or positive wit].50

This is not a description of simple intuition. Only at the conclusion of a complex methodical, incremental deduction can the licence and the commandment of an evidential image be formulated. It is the aim of every Romantic call for popularity to create such evidential images - in philosophy, in polemics and in poetry particularly in the genres of the song, the fairy tale and the saga. With its reflections on the 'An- und Umbilden' [imagination and re-imagination] of existing texts, the conception of a 'New Mythology' seeks to create novel, impressive images from traditional myths and legendary topics. ${ }^{51}$ Clemens Brentano's Loreley is a successful, popular attempt to relocate the Siren myth from Greek mythology to the Rhine legend. By the same token, the Brothers Grimm's concept of popularity also makes use of evidential images. Obviously, unlike Fichte's, these images do not spring from high pathos, but rather from their closeness to the 'simplicitas majestatis' usually reserved for biblical texts. From this perspective, the poetic fairy tale is self-evident, necessary, its existence uncontroversial; neither does it need to be defended, nor is it necessary to employ rhetoric in order to convince others of its value. Its existence provides its evidence: fiat lux. This conviction is clearly witnessed by a quote from the prologue to the Brothers Grimm's fairy tales: 'Wir wollen in gleichem Sinne diese Märchen nicht rühmen oder gar gegen entgegengesetzte Mei- 
nung verteidigen: ibr bloßes Dasein reicht hier, sie zu schützen. Wer so mannigfach und immer wieder von neuem erfreut, bewegt und belehrt hat, trägt seine Notwendigkeit in sich und ist gewiss aus jener ewigen Quelle gekommen, die alles Leben betaut' [By the same token, we do not intend to glorify these fairy tales, let alone defend them against opposed opinions: by their mere existence they are sufficiently protected. Things which time and again and in so many ways spread joy, move the heart of men and educate their minds have their own inherent necessity and surely spring from the same source that nourishes all life]. ${ }^{52}$ In the case of the brothers Jacob and Wilhelm Grimm, such a certainty derived from evidential images. ${ }^{53}$ This is based on a highly speculative (and as we now have come to learn historically untenable) yet poetically fruitful supposition of 'geheimer, verlorengegangener Berührungen der Märchen mit der eigenen mythischen Herkunft' [arcane, long-lost points of contact between the fairy tales and one's own mythological origin]. ${ }^{54}$ The connection between the Brunhilde myth from the song of the Nibelungen and the tale of Sleeping Beauty lacks any historical basis whatsoever; nevertheless, the formidable depiction of the slow awakening of man and nature is derived from natural philosophy. The quest for Romantic evidential images was a highly complex and artificial endeavour. It was marked by an elaborate interplay between writing and the oral tradition, as well as by an exhaustive use of inter-medial means to mobilise the imagination. For example, the final image of the tale Rumpelstilzchen [Rumpelstiltskin] is an attempt to channel the affect of utter fury, the rage at the revelation of one's identity into one cipher in a haptic, schematic manner: Besides itself with rage, Rumpelstiltskin stomps a deep hole into the ground, and standing with its legs spread far apart, it then tears itself in half by suddenly pulling up its other leg. This evidential image is not part of the traditional lore, but rather the result of the style employed by the Brothers Grimm.

To summarise: Romantic popularity is constructed from the predominance of scholarly interest over interest in public opinion, from the witty evidence of an intellectual perspective, from a recipient ready to embrace new visions of the future, a recipient who is aware of the dynamics of knowledge and of the historical change in communication horizons. The Romantic conception of popularity refuses any kind of intentional conveyance. Adam Müller states 'und so ist Popularität im echten Sinne nichts anderes als der notwendige, und obne irgendeinen Vorsatz, aller wissenschaftlichen und künstlerischen Wirksamkeit innewohnende Geist der Bewegung und des Fortschreitens' [in its truest sense, popularity is therefore nothing else but the necessary, completely intent-free spirit of movement and progress which is inherent to all scholarly and artistic work]. The polemical tone targeting popular philosophers is hard to miss in this observation: 'Bei dem misslingenden, hochmütigen Herablassen der Autoren wird nichts begünstigt als gerade der flache Egoismus der Zeitgenossen, ibr Scheinleben und Scheinwissen. Deshalb habe alles Wissen eine persönliche Gestalt, ein unabhängiges Leben, Fleisch und Mark - es sei nur von Hause aus gemütlich, das heißt, kräftig, das heißt künstlerisch: und es wird von selbst schon wachsen und ergreifen und befruchten' [With their failing, haughty condescension, the authors benefit 
nothing but the shallow egotism of their contemporaries, their pseudo-lives and their pseudo-knowledge. That is why all knowledge ought to have a personal guise, a life of its own, flesh and bone - it only needs to be jovial in its nature, that is, strong, that is artistic: and it will grow and become captivating and fertilising all by itself]..$^{55}$

Starting from here, the alternative to the conception of popularity of the Enlightenment becomes all too obvious - with its 'tötenden Verallgemeinerung ${ }^{56}$ [destructive generalisation], i.e. with its erosion of the individual in the name of objectivity, ${ }^{57}$ its methodical tendency 'alle einzelnen Bildungsarten abzuschleifen und auf den mittleren Durchschnitt $z u$ bringen ${ }^{58}$ [to level out all kinds of education to the medium average] - and by the same token, with its stylistic tendency towards mediocrity, which is - to quote from a 'moral weekly' entitled Der Patriot: 'Weder für die Gelehrten zu schlecht und zu niedrig, noch für die Ungelehrten zu hoch und unbegreiflich, sondern jedermann verständlich' [neither too worthless and low for scholars nor too sophisticated or unfathomable for non-scholars, but intelligible for everyone]. ${ }^{59}$

This article could be concluded at this point. In that case, however, we would pass up the opportunity to discuss the controversial and problematic nature of the Romantic concept of popularity as well as its new dogmatism. Hence, a short addendum. The habitual and socio-political centre of both alternative conceptions of popularity can be located by examining their respective stances on tolerance. In his seventh volume of Dichtung und Wabrheit [Poetry and truth], Johann Wolfgang von Goethe translated the mediocrity of the popular philosophers, much-maligned by Romantics, to a neutral and non-pejorative perspective: According to him, the achievement of the popular philosophers was to support a 'besondere Mäßigkeit' [particular moderation] by insisting on the middle course and on tolerance toward all opinions as the right way. ${ }^{60}$ As noted by Knigge in the last chapter of his Über den Umgang mit Menschen [On human relations], 'Über das Verhältnis zwischen Schriftsteller und Leser' [On the relationship between the author and the reader], this tolerance also included a certain composure and tolerance in terms of writing styles, as long as they did not veer toward the 'Unsittlichen' [immoral], 'Boshaften' [malicious], 'Schädlichen' [harmful] and 'Unsinnigen' [nonsensical]. ${ }^{61}$ The mercilessness, relentlessness, and acridity of Romanticism are aimed precisely at this random tolerance of popular philosophy which refuses 'streng zu scheiden' [to strictly separate] 'Gutes und Schlechtes' [good from bad] be it in opinion or in style. ${ }^{62}$ Two quotes epitomise this attitude: 'Das ist es eben, wovon man nicht wissen will in diesem artigen Zeitalter, wo der Mensch und die Tugend und alles in einen so glatten und geschmeidigen Conversationston gefallen sind, dass die Wabrheit selbst lieber unwahr und unhöflich sein darf [This is precisely what no-one cares about in this well-behaved age in which man and virtue and everything have been clad in such a smooth and elegant conversational tone that the truth itself may rather be untrue and impolite]. ${ }^{63}$ This nearly fanatic acridity becomes all too obvious when Schlegel speaks 'von der absoluten Entgegengesetztheit der Wege' [of the diametric opposition of directions]: 'Es giebt zwei ursprünglich verschiedene Tenden- 
zen im Menschen, die aufs Endliche und Unendliche, also nicht bloß eine Verschiedenheit des Grades, Nuancen von Tugend und Laster, sondern absolute Entgegengesetztheit der Wege, die es jedem Menschen freisteht zu wandeln' [There are two basic, different tendencies in mankind - one towards the finite and the other towards the infinite - that is, not merely different in terms of the degree or the nuances of virtue and sin, but a diametric opposition of the directions everyone is free to take]. ${ }^{64}$ It is only against this background that we can understand why Schlegel tends to transfer the Zoroastrian battle between 'dem guten und bösen Prinzip' [the good and the evil principle] as embodied in the figure of 'Ahriman' to the mediocrity of that era. ${ }^{65}$ The dogmatic implications of this polemics should be obvious. 


\section{Notes}

1 Immanuel Kant, 'Was ist Aufklärung', in Sämmtliche Werke, vol. 5 (Berlin: L. Heimann, 1872), 111. For the concept of 'sociality', see Kurt Wölfel's epilogue to Christian Garve, Popularphilosophische Schriften über Literarische, Ästhetische und Gesellschaftliche Gegenstände [1796], ed. Kurt Wölfel (Stuttgart: Metzler, 1974), 34 .

2 Wölfel, ed., Populärphilosophische Schriften, 41.

3 Friedrich Schlegel, Philosophische Lehrjahre, 1796-1806, in Kritische Friedrich-Schlegel-Ausgabe, ed. Ernst Behler, vol. 18 (München: F. Schöningh, 1963), 228. Henceforth abbreviated as K.A.

4 Werner Schneiders, 'Popularphilosophie', in Lexikon der Aufklärung. Deutschland und Europa, ed. Werner Schneiders (München: C. H. Beck, 1995), 326.

5 Ibid.

6 Friedrich Schlegel, 'Ueber die Philosophie: An Dorothea', in Athenaeum: Eine Zeitschrift von August Wilhelm und Friedrich Schlegel (1799), 2. vols. (reprint, Dortmund: Bernhard Sorg, 1989), 411.

7 Europa: Eine Zeitschrift, ed. Friedrich Schlegel (1803),. (Darmstadt: Wissenschaftliche Buchgesellschaft, 1973), 54 .

8 Schlegel, Athenaeum, 406.

9 Ibid., 407.

10 Ibid.

11 Ibid., 411.

12 Adam Müller, 'Popularität und Mystizismus', in Adam Müller, Kritische, Ästhetische und Philosophische Schriften, ed. Walter Schroeder and Werner Siebert (Neuwied und Berlin: Luchterland, 1967), 500.

13 Joachim Ritter, 'Aesthetik, Ästhetisch', in Historisches Wörterbuch der Philosophie, ed. J. Ritter, vol. 1 (Basel, Stuttgart: Schwabe, 1971), 557.

14 Friedrich Wilhelm von Ramdohr, 'Kunst der Schönen Geselligen Unterhaltung', in Friedrich Wilhelm von Ramdohr, Studien zur Kenntnis der Schönen Natur, der Schönen Künste, der Sitten und der Staatsverfassung auf einer Reise nach Dänemark (Hannover, 1792).

15 Wolfgang Martens, Die Botschaft der Tugend: Die Aufklärung im Spiegel der deutschen moralischen Wochenschriften (Stuttgart: Metzler, 1968), 147

16 Gottfried August Bürger, Sämtliche Werke, ed. Günter and Hiltrud Häntzschel (München, Wien: C. Hanser, 1987), 730.

17 Ibid., 717 .

18 Ibid., 13.

19 Doris Bachmann-Medick, Die Ästhetische Ordnung des Handelns: Moralphilosophie und Ästhetik in der Popularphilosophie des 18. Jabrhunderts (Stuttgart: Metzler 1989), 63, 65, and 140. Cf. Christoph Böhr, Philosophie für die Welt: Die Popularphilosophie der deutschen Spätanfklärung im Zeitalter Kants (Stuttgart-Bad Cannstatt: Frohmann-Holzboog, 2003).

20 Immanuel Kant, Foreword to Logik, in Gesammelte Schriften, vol. 9 (Berlin: Der Königlich-Preussischen Akademie der Wissenschaften zu Berlin, 1902), 62.

21 Christian Garve, Von der Popularität des Vortrages (1793 and 1796), in Wölfel, ed., Populärphilosophische Schriften, 1039.

22 Christian Garve to Immanuel Kant, 13 July 1783, in Kant's Briefwechsel, vol. 1, 1747-1788 (Berlin und Leipzig 1922), 331. 
24 Immanuel Kant to Christian Garve, 7 August 1783, in Wölfel, ed., Populärphilosophische Schriften, $336 f$.

25 Ibid., 338.

26 Ibid., 331f.

27 Ibid., 339 and annotations.

28 Ibid., 338.

29 Ibid., 339.

30 Ibid., 341.

31 K.A. 2, 97.

32 Immanuel Kant to Garve, in Wölfel, ed., Populärphilosophische Schriften, 341.

33 Ibid., 351 [1059].

34 Ibid., 352 [1060].

35 Johann Christoph Greiling, Theorie der Popularität [1805] (reprint, Stuttgart-Bad Cannstatt, 2000), 163 .

36 K.A. II, 111.

37 K.A. 18 (1963), 221, no. 318.

38 K.A. 18,220 , no. 318.

39 Friedrich Schleiermacher, 'Garves letzte von ihm selbst herausgegebene Schriften', in Athenaeum $3.1(1800), 136$.

40 Cf. Heinrich Bosse, Autorschaft ist Werkherrschaft (Paderborn: Schöningh, 1981), 131f.

41 K.A. 18,215 , no. 244.

42 K.A. 2, XXVII.

43 Cf. the relevant article by Holger Dainat, " "Meine Göttin Popularität". Programme Printmedialer Inklusion in Deutschland 1750 - 1850', in Hedwig Pompe and Jens Ruchatz, eds., Popularisierung und Popularität (Köln: DuMont Verlag, 2005), 52.

44 Johann Gottlieb Fichte, 'Über die Bestimmung des Gelehrten', in Fünf Vorlesungen 1794 (Stuttgart: Verlag Freies Geistesleben, 1959), 42f.

45 Hans Freyer, 'Über Fichtes Machiavelli - Aufsatz', in Bericht über die Verhandlungen der Sächsischen Akademie der Wissenschaften (Leipzig: S. Hirzel, 1936).

46 Johann Gottlieb Fichte, 'Über das Wesen des Gelehrten und seine Erscheinungen im Gebiete der Freiheit', in Vorlesungen gehalten zu Erlangen im Sommerhalbjabre 1805 (Leipzig: F. Meiner, 1921), 11.

47 One of the most crucial points of Romanticist criticism regarding Garve's stance on popular philosophy is his affirmation of his own era [cf. K.A. 18, 343].

48 Fichte, 'Über die Bestimmung des Gelehrten', 27.

49 Ibid., 31.

50 Johann Gottlieb Fichte, Grundzüge des Gegenwärtigen Zeitalters in Vorlesungen, Gehalten zu Berlin, im Jahre 1804-1805, in Ausgewählte Werke in sechs Bänden, ed. Fritz Medicus, vol. 4 (Stuttgart: Frommann-Holzboog,1962), 469.

51 K.A. $2,318$.

52 Brüder Grimm, Kinder - und Hausmärchen. Ausgabe letzter Hand, ed. Heinz Rölleke, vol. 1 (Stuttgart: Reclam Bibliothek, 1982), 16. 
53 Cf. the most recent methodical considerations regarding the necessity and the limits of evidence in Elke Vöhnicke, Das Unbewußte im Deutschen Idealismus (Würzburg: Königshausen \& Neumann, 2005).

54 Cf. Jens E. Sennewald, Das Buch, das Wir Sind: Zur Poetik der 'Kinder-und Hausmärchen, Gesammelt durch die Brüder Grimm' (Würzburg: Königshausen \& Neumann, 2004), 140f.

55 Both quotations from Müller, Kritische, Ästhetische und Philosopische Shriften, 500. For a critical commentary see Hermann Bausinger, 'Herablassung', in Eberhard Müller, ed., ‘. . aus der anmuthigen Gelebrsamkeit': Tübinger Studien zum I8. Jabrbundert. Dietrich Geyer zum Geburtstag (Tübingen: Attempto-Verlag, 1988), 25-39.

$56 \quad$ K.A. $2,286$.

57 Garve, Populärphilosophische Schriften, 1065.

58 K.A. 2, 268, no. 123.

59 Gert Ueding, 'Popularphilosophie', in Historisches Wörterbuch der Rhetorik, ed. Gert Ueding, vol. 6 (Tübingen: Max Niemeyer Verlag, 2003), 1553.

6o Johann Wolfgang Goethe, Dichtung und Wabrheit, in Autobiographische Schriften, vol. 10 (München: C. Bertelsmann Verlag, 1957 ), 249.

61 Adolph Freiherr von Knigge, Über den Umgang mit Menschen (Bremen: Carl Schünemann Verlag, 1964), 43of.

62 K.A. 18, 524.

63 Ibid., 525.

64 Ibid., 524.

65 Schlegel, Europa, 54. 